\title{
The Protection of Investor Rights in Margin Transactions By Securities Companies when Force Selling is Performed
}

\section{Ratu Vidi Sulistyani*), Anis Mashdurohatun*) and Lathifah Hanim**)}

${ }^{*}$ ) Faculty of Law, Universitas Islam Sultan Agung (UNISSULA) Semarang, E-mail: ratuvidi@yahoo.com

${ }^{*}$ Faculty of Law, Universitas Islam Sultan Agung (UNISSULA) Semarang

*) Faculty of Law, Universitas Islam Sultan Agung (UNISSULA) Semarang

\begin{abstract}
.
The purpose of this study is to analyze investor rights protection arrangements in the analysis of margin transaction financing and the implementation of investor rights protection arrangements in the analysis of margin transaction financing by Stock Exchange Companies when a share sale is forced. The research method applied is sociological juridical. The results of this study show the regulation on the protection of investor rights in the analysis of margin transaction financing by a Stock Exchange Company when a share sale is made by force has actually been regulated in a letter of agreement, which is stated in Bapepam-LK Rule Number VD6. The existence of these regulations has fulfilled the legal protection aspects for investors as regulated in the Civil Code, but has not fulfilled the investor legal protection aspects as regulated in the Capital Market Law and the Consumer Protection Law. The implementation of the protection of investors' rights in the analysis of margin transaction financing by the Stock Exchange Company when a forced sale of shares is carried out has been carried out through a contract accompanied by the implementation of an internal control system and the implementation of haircuts by the IDX.
\end{abstract}

Keywords: Forced; Protection; Sell; Transactions.

\section{Introduction}

Investment in the capital market is one source of funds to finance national development ${ }^{1}$. One of the functions of the capital market is to become a financing facility that brings together investors as parties who have more funds with issuers, namely parties who are in need of funds. ${ }^{2}$. One of the efforts that can be made to increase interest in investment is to create a conducive climate, especially those related to overcoming issues in the field of law enforcement ${ }^{3}$. The importance of law enforcement, in the field of investment, can be applied when there is a forced sale. A forced sale, also known as a forced sell, is an agreement agreed by the

\footnotetext{
${ }^{1}$ Agung Sudjati Winata, "Perlindungan Investor Asing dalam Kegiatan Penanaman Modal Asing dan Implikasinya Terhadap Negara”, AJUDIKASI: Jurnal Ilmu Hukum, Vol. 2 No. 2. December 2018. p.

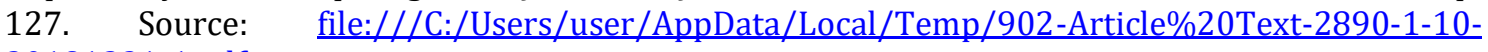
20181231-1.pdf,

2 Bagus Sujatmiko and Nyulistiowati Suryanti, "Perlindungan Hukum Bagi Investor Pada Perusahaan Terbuka Yang Pailit Ditinjau dari Hukum Kepailitan”, Jurnal Bina Mulia Hukum Volume 2, No. 1 , September $2017 . \quad$ p. $16 . \quad$ Source:
} https://jurnal.fh.unpad.ac.id/index.php/jbmh/article/view/88/41,

${ }^{3}$ Ria Sintha Devi, "Perlindungan Hukum Bagi Penanaman Modal Asing (PMA) Di Indonesia", Jurnal Rectum, volume I, No. 2, July $2019 . \quad$ p. $142 . \quad$ Source: https://jurnal.darmaagung.ac.id/index.php/jurnalrectum/article/view/227 
securities party with the customer ${ }^{4}$. This forced sell occurs when the stock value is at a forced sale ratio, where this condition occurs when the customer's margin ratio reaches $80 \%$, which causes the company to have full authority to sell part or all of the securities in the customer's margin securities account. ${ }^{5}$ The forced sell becomes a risk when there is margin trading or a decline in the value of shares, which requires the customer to add collateral or liquidate or sell the shares they hold to a securities company. ${ }^{6}$. Usually in margin trading, a forced sell occurs if the regular account customer up to $\mathrm{T}+4$ is unable to settle the purchase obligation that matures on $\mathrm{T}+2$, then the shares in the customer's regular account will be forced to sell for the customer's obligation 7 .

The implementation of a forced sell usually requires an involuntary sale of assets or securities to create liquidity in the event of an uncontrollable or unforeseen situation. Forced sales are usually carried out in reaction to economic events, changes in personal life, company regulations, or legal arrangements. A forced sell can refer to a number of situations where an individual asset is required to be sold. In the investment world, if a margin call is issued and investors cannot bring their investment to the minimum requirements, the broker has the right to sell shares. In personal finance, individual assets can be liquidated for various reasons including: bankruptcy, divorce, or death. In the field of security investment, A forced sale can occur in an investor's margin account if the investor fails to bring their account above the minimum requirements after being granted a margin call. A forced sell generally occurs after a warning is issued by the broker, regarding the under-margin status of an account. If the account holder chooses not to meet the margin requirements, or is unable to pay them, the broker has the right to sell the current shares ${ }^{8}$.

In the implementation of a forced sell, there is actually a calculation, as in the agreement with the broker, where a forced sell occurs when the stock purchased on margin has decreased by a certain percentage or if the limit of days in the use of margin has reached the limit, then a forced sell can be done ${ }^{9}$. The occurrence of a forced sell can also be carried out without the prior consent of the investor, and the broker has the right to choose the securities to be sold in order to reduce the risk faced by selling on the regular market. In addition, before the customer's debit balance falls below or equal to the maintenance ratio margin, all purchasing activities are suspended, and when the customer violates these

\footnotetext{
${ }^{4}$ Ocbc Securities. Securities Transaction Financing Agreement Margin Securities Financing Account Agreement for Margin Transaction. Article 13 Regarding Forced Sales. 2018.

5 Ibid.

${ }^{6} J u l y$ Asril, "Margin Trading in the Capital Market and its Regulations in Indonesia", Scientific Journal of Mea (Management, Economics, \& Accounting), Vol. 3, No. 1, 2019. 256-273. page. 263.

${ }^{7}$ Anonymous. Avoid Forced Sell When Using Limit Trading With Margin Facility. Included in Most, Issue 26 March 2020. Source: Https://Www.Most.Co.Id

${ }^{8}$ Alicia Tuovila. 2021. Forced Selling (Forced Liquidation). Source: Investopedia, Edition 30 Juni 2021. Diakses Dari: Https://Www.Investopedia.Com

9 Kiki Safitri, "Mau Main Saham Pakai Margin Trading, Pahami Mekanismenya Supaya Tidak Terjebak Kerugian", Kompas, Edition 20 January 2021. Accessed from Https://Money.Kompas.Com,
} 
provisions, the company has the right to close the securities account for financing the customer's margin transaction even though the agreement has not ended ${ }^{10}$.

The forced sell regulation is contained in Act No. 8 of 1995 concerning the Capital Market, but the existence of this regulation does not fully explain the forced sell action. In addition, the regulation regarding forced selling has actually been contained in Bapepam Regulation Number VD6 concerning Financing of Securities Transactions by Securities Companies for Customers and Short Selling Transactions by Securities Companies which was amended by Decree of the Chairman of Bapepam-LK, No. Kep. 258/ BL/ 2008. The regulation contains many requirements for customers, exchange members who can do financing, traded securities, and the main points of agreement that must be included in margin transactions. ${ }^{11}$ However, in the regulation there are still weaknesses, where there is no clear monitoring mechanism for compliance with these regulations. This condition is also reinforced by the abundant evidence that Bapepam is negligent in supervising the capital market ${ }^{12}$.

This oversight by Bapepam can be exemplified by the impact on several issues, such as the emergence of problems in the field, especially those caused by the absence of the principles of good faith (accurate and complete disclosure of information) and good communication (providing information to investors openly and quickly), which is very much needed. in the contract agreement in the margin transaction made by the securities company. Where if one of these principles is not implemented, then margin transactions will cause problems. This is as found in the case of PT. DBS Vickers Indonesia, which was revealed in 2009, used customer funds for a forced sale of a margin transaction account in Dedy Hartawan's regular account which indicates a violation of regulations, where a forced sell can be made on a margin account, besides that, the customer also reports that the securities company has traded securities without the customer's approval, in this case the customer has lost funds in his securities account of up to $\mathrm{Rp} 90$ billion. As a result of this incident, the customer suffered a loss from the forced sell, so this needs to be given more attention, because the characteristics of margin transactions have a relatively high risk.

The weakness of supervision that should have been carried out by Bapepam also had an impact on the occurrence of forced sells, which was caused by the problem of manipulation of stock prices carried out by PT Sekawan Intripratama Tbk (SIAP) in 2014, and carried out by PT Dharma Samudera Fishing Industries (DSFI) and Primarindo Asia Infrastructure (BIMA) in 2002, all of which of course brought losses to customers $^{13}$, due to the manipulation of the share price,

10 Chuasanga A., Ong Argo Victoria, "Legal Principles Under Criminal Law in Indonesia and Thailand", Jurnal Daulat Hukum, Vol $2, \quad$ No 1 (2019) http://jurnal.unissula.ac.id/index.php/RH/article/view/4218

11Fitria Dina. 2015. Perlindungan Hukum Terhadap Investor Dalam Hal Jual Paksa (Forced Sell) Di Pasar Modal (Studi Di Pt. Bni Securities Padang). Diploma Thesis, Upt. Perpustakaan Unand. URL. https://onesearch.id/Record/IOS3153.115, p. 17.

${ }^{12}$ Anonymous. Op.cit.

${ }^{13}$ Ibid. 
furthermore, the customers are unable to make payments, so this triggers a forced sell which is certainly detrimental to these customers.

The forced sell practices carried out by the company as exemplified above are deliberately carried out as a result of the weakness of existing regulations that do not contain the supervisory mechanism that must be carried out by Bapepam, thus providing opportunities for weaknesses in the supervision carried out by Bapepam. As a result, this will certainly result in losses that must be experienced by investors, as a result of injuring the rights of investors in obtaining legal protection, which in turn has an effect on public confidence in the securities company. Based on these issues, it is appropriate to question the protection of investors regarding their shares which are sold without notification or approval and a transparent mechanism. ${ }^{14}$.

In accordance with these problems, it is necessary to research on legal reforms that are applied to protect investors' rights in the analysis of margin transaction financing by Stock Exchange Companies when selling shares by force, because so far there has been a problem of regulatory weakness in forced sales which is detrimental investors. These weaknesses can be seen in the contradictions contained in Bapepam-LK Regulation Number VD6 Financing of Securities Transactions by Securities Companies for Customers and Short Selling Transactions by Securities Companies number 4 which contradicts the legality of standard clauses in the Consumer Protection Law, as well as the absence of further regulation further regarding the mechanism of forced selling of shares so that crossing practices that tend to harm customers/investors can be avoided,

This research was also conducted to answer the weaknesses in previous research, as the results of previous research conducted by Linda Ismaya (2014) which found a conflict between the legal protection of investors as regulated in the Capital Market Law and the Consumer Protection Act. In addition, this study also complements the weaknesses carried out by previous researchers, namely Verdy J. Pangaribuan (2012) who has a weakness that is the act of violating Bapepam-LK Regulation No. VD6 of 2008, especially those carried out through force selling in accordance with applicable regulations, which must be followed up by determining the criteria for securities in accordance with the provisions of the applicable Bapepam-LK regulations.In accordance with these problems, in order to be able to answer existing problems related to the need for legal updates that can be applied to provide protection for investors' rights in the analysis of margin transaction financing by Stock Exchange Companies when there is a forced sale of shares.

Based on the background explanation above, this research is aimed at analyzing the arrangements for protecting investors' rights in the analysis of margin transaction financing by Stock Exchange Companies when a stock is sold by force and the implementation of investor rights protection arrangements in the analysis of margin transaction financing by Stock Exchange Companies when selling shares.

${ }^{14}$ Jusuf Anwar. (2005). Pasar Modal Sebagai Sarana Pembiayaan dan Investasi. Bandung: Alumni, p. 220. 


\section{Research Methods}

The research approach used is a sociological juridical approach. The source of the data for this research comes from secondary data sources that come from information in the form of data, reports, and statutory regulations. Data collection techniques that researchers use in research include interviews. Data analysis was carried out by qualitative descriptive analysis.

\section{Results and Discussion}

The results of the study show that margin trading and forced sell transactions are not regulated in Act No. 8 of 1995 concerning the Capital Market. The Capital Market Law only regulates general transactions while special transactions are regulated outside the law. Margin trading and forced sell transactions are regulated by Bapepam-LK Regulation (now OJK) Number VD6 concerning Financing for Settlement of Securities Transactions by Securities Companies for Customers and Jakarta Stock Exchange Regulation Number 19 of 1997 concerning Margin Transactions, Decree of the Chairman of Bapepam-LK No. Kep556/BL/2008 concerning Financing of Securities Transactions by Securities Companies for Customers and Short Selling Transactions by Securities Companies, and Financial Services Authority Regulation Number 21/P0JK.04/2019,

To anticipate transactions that could cause the JCI to fall further, Bapepam issued a number of regulations, including the revision of the forced sell rule. This forced sell transaction was then regulated, among others, by Decree of the Chairman of Bapepam-LK No. 556/BL/2008 and Financial Services Authority Regulation Number 21/POJK.04/2019. This regulation regulates the Financing of Securities Transactions for Customers and Short Selling Transactions by Securities Companies. The Stock Exchange is required to stipulate Stock Exchange regulations that regulate the requirements for Securities that can be transacted with financing by Securities Companies and which can be used as collateral for financing in securities transactions. Forced sell transactions which resulted in the current condition of the capital market experiencing instability so that the impact on the world economy became volatile ${ }^{15}$. So, basically forced sell transactions in Indonesia are allowed. However, Bapepam-LK still determines what signs of forced sell transactions are allowed. The goal, of course, is to secure the domestic capital market in addition to the interests of minority investors.

Arrangements regarding margin trading and forced sell transactions are related to the arrangements in Book III of the Civil Code, especially the arrangements regarding agreement issues that occur in margin trading and forced sell transactions. Agreements in margin trading and forced sell transactions occur between the two parties where one party promises the other party to do something. This is in accordance with Article 1313 of the Civil Code, which states: "An agreement is an act by which one or more persons bind themselves to one or

\footnotetext{
15 Decision of the Chairman of BAPEPAM-LK Number KEP-556/BL/2008 Financing of Securities Transactions by Securities Companies for Customers and Short Selling Transactions by Securities Companies
} 
more persons". Civil law applicable in Indonesia recognizes the existence of freedom of contract, this can be concluded from the provisions of Article 1338 paragraph (1) of the Civil Code, ${ }^{16}$.

The source of freedom of contract is individual freedom, so that the point of departure is individual interests as well. So that the nature of book III of the Civil Code is open and opens the possibility of agreements that have not been regulated in the Civil Code concretely, but still in accordance with the principles and conditions of a valid agreement in the Civil Code, in other words it is allowed to override the regulations contained in the third book. ${ }^{17}$.

The agreement made must be in accordance with Article 1320 of the Civil Code in order to have binding force, so that with the principle of freedom of contract and the open nature of book III of the Civil Code, the parties in margin trading and forced sell transactions are free to determine the contents of the agreed contract which will ultimately result in binding on both parties ${ }^{18}$. Agreements that occur in margin trading and forced sell transactions can use article 1313 of the Civil Code as a setting, so that what is a legal requirement for an agreement contained in the Civil Code must be considered so that the imposition of agreement rules in Indonesia which generally use the Civil Code can be applied as well as agreements in transactions margin trading and forced sell can be recognized as valid.

However, the civil law applicable in Indonesia recognizes the existence of freedom of contract, this can be concluded from the provisions of Article 1338 paragraph (1) of the Civil Code, which states that all contracts (agreements) that are made legally apply as law for those who make them. The subject matter of margin trading is the contract between securities companies and investors. Margin trading has the potential to cause disputes between customers or investors and securities companies, for example if one of the parties violates the agreed contract. Therefore, in this margin trading transaction the principles of good faith and good communication should apply.

To strengthen this explanation, the regulation on the protection of investor rights in margin transactions when a sale of shares is carried out forcibly is also strengthened by the explanation of Article 4 of Act No. 8 of 1995 on the Capital Market which states that "Guidance, regulation, supervision as referred to in Article 3 is carried out by Bapepam with the aim is to create an orderly, fair and efficient Capital Market activity as well as to protect the interests of investors and the public."

The Regime of Act No. 8 of 1995 concerning Capital Markets (hereinafter referred to as UUPM) determines and stipulates that the authorized authority on the capital market is Bapepam-LK. This authority is under the Ministry of Finance to develop, regulate and supervise the capital market. In its activities, Bapepam-LK

\footnotetext{
${ }^{16}$ Subekti and R. Tjitrosubidio, 1996, Kitab Undang-Undang Hukum Perdata. Jakarta: PT. Pradnya Paramita, p. 345.

${ }^{17}$ Endi Budiman, 2010, Perlindungan Hukum terhadap Perusahaan Sekuritas dalam Transaksi atas Fasilitas Margin Trading. Semarang: Universitas Diponegoro, p. 101.

${ }^{18}$ Op. cit. p. 339
} 
is under and responsible to the Minister of Finance. Bapepam-LK has the authority to carry out preventive and repressive legal protection for the capital market.

To protect investors, the issuer who will sell securities in a Public Offering must provide the opportunity for investors to read the prospectus regarding the securities issued, before the order or at the time the order is placed. In the end, after Bapepam-LK paid attention to the completeness and clarity of the issuer's documents to conduct a Public Offering in order to comply with the principle of capital market transparency. This is important considering that the prospectus for securities is the initial door and time for investors to consider whether or not to decide to buy a security.

The next precautionary measure taken by Bapepam-LK is to stipulate that the securities prospectus are prohibited from containing misleading content or incorrect information regarding material facts 19 or presenting information about the advantages and disadvantages of the securities offered. In practice, BapepamLK standardizes the preparation of the prospectus for the securities to be offered. This protective measure begins when Bapepam-LK grants licenses to SROs, mutual funds, securities companies, and supporting professions to operate in the capital market.

In addition to preventive measures, Bapepam-LK is also authorized to carry out inspections and investigations. This is a consequence of the supervisory function given by law to Bapepam-LK. Examination activities are carried out on all parties suspected of having, being, or trying to commit or ordering, participating, persuading, or assisting in violating the capital market law and its implementing regulations. ${ }^{19}$.

The real form of legal protection that is right for dealing with cases like the one above is by taking preventive and repressive legal protection measures. This legal protection measure is also closely related to the rights of consumers to take advantage of financial service institutions. Preventive action that can be taken by the stock exchange authority to prevent system disturbances from happening again is to provide guidance and consumer education. This is in accordance with Article 4 letter $\mathrm{f}$ of the UUPK. The Exchange provides education for stock exchange members as well as consumers who have registered as investors about securities transactions and simulations of actions (mock trading) that must be carried out by stock exchange members and investors in the event of force majeure on the transaction equipment.

The objects in the margin transaction financing agreement between a securities company and its customers are funds and securities where the types of both objects are clear and can be calculated and the amount determined. The margin transaction financing agreement is made based on the economic needs of both parties. Meanwhile, the element of legal competence in the margin transaction financing agreement can be seen from the validity of the agreement to open a regular securities account where the customer must already have a regular securities account with the same securities company first. The customer is deemed

${ }^{19}$ Irsan Nasaruddin, et.all, 2011, Aspek Hukum Pasar Modal Indonesia, cet. 7. Jakarta: Kencana Prenada Media Group, p. 117. 
to have agreed with the securities company regarding the contents of the agreement if the customer accepts and signs an agreement containing the clause.

Legal protection includes preventive and repressive legal protection ${ }^{20}$. As a preventive measure there must be a law which in the process of its formation is given the opportunity for all parties to express opinions and objections before the official formation of regulations. The Financial Services Authority carries out the regulatory function carried out by the Board of Commissioners, while the supervisory function is carried out by the Chief Executive who oversees the respective fields of capital market, banking and non-bank financial institutions where the Chief Executive also serves as the Board of Commissioners. The formulation of regulations and policies is carried out with input from each Chief Executive based on a study of problems and regulatory needs in the field. The Chief Executive in the capital market sector will be the party representing the interests and needs of capital market participants.

The law that will be formed must protect human rights because legal protection in principle is the implementation of the recognition and protection of human dignity and the concept of the rule of law itself. Similar to Jimly's opinion regarding the protection of human rights as one of the elements of a state of law, ${ }^{21}$ protection of human rights is one of the important elements of the rule of law concept.

Human rights as stated in Article 28A paragraph (1) are "rights to recognition, guarantee of protection and fair legal certainty and equal treatment before the law". Each individual also has the right to obtain information as stated in Article 28F. Article 28H paragraph (4) states that citizens have "rights to private property which cannot be taken over arbitrarily by anyone".

The foregoing has the consequence that shares in margin transactions recorded in accounts belonging to customers/investors cannot be sold arbitrarily by securities companies and that customers/investors have the right to obtain information on everything related to shares in his account. Transparency, credibility and professionalism in the capital market are the main requirements and keys in addition to the importance of supervision from the capital market authorities.

The purpose of preventive legal protection is to prevent disputes from occurring. Therefore the law must be able to protect the interests of the parties in it. The forced sale of shares as regulated in Bapepam-LK Regulation Number VD6 is seen as a legal protection measure for securities companies from their customers who do not fulfill the obligation to fulfill guarantees to keep the financing ratio at the specified limit.

Protection of securities companies is carried out by limiting the interests of other parties in this case are customers or investors. This means that legal protection for customers/investors must be carried out in the opposite way, namely limiting the interests of securities companies through a new law. Legal

\footnotetext{
${ }^{20}$ Phillipus M. Hadjon, 1988, Perlindungan Hukum bagi Rakyat Indonesia. Surabaya:Bina Ilmu, p. 5. ${ }^{21}$ Jimly Asshiddiqie. No year. Konsep Negara Hukum. Source: www.jimly.com. Accessed on 4 August 2021 at 11:10 WIB
} 
products that are formed as preventive legal efforts must also be predictive so that the law can provide legal guarantees and certainty.

Repressive legal protection aims to resolve disputes or problems that arise. This protection is related to law enforcement and the supervisory function of OJK. OJK can be a facilitator in order to resolve differences between actors in the capital market. The function of notification transparency, the mechanism for the sale of shares by force, confirmation of the results of the sale of shares, and dispute resolution are at the core of the whole process of selling shares by force. This whole process must reflect legal protection for investors whose parameters can be seen from the existence of preventive legal protection and repressive legal protection.

Based on the results of the discussion above, it can be seen that there is no form of legal protection for investors in the capital market which is specifically regulated in the Act. Investors who make transactions in the capital market are generally considered to have extensive knowledge (smart investors). This knowledge indicates that there is no loss that will be experienced during the transaction. However, every investor has weaknesses, and there is a need for protection from parties who can harm or want to gain profits by exploiting the weaknesses of investors. Negotiated market is a protection provided by the stock exchange to investors before an issuer is officially delisted.

The implementation of the protection of investors' rights in the analysis of the financing of margin transactions by a stock exchange company when a share sale is made forcibly is stated in the form of an agreement which is the principle of implementing the principle of freedom of contract between a securities company and its customers/investors, one of which is the rights and obligations of the parties as a form of legal protection. This principle is a topic in every legal study relating to contracts. This may be the most important domain in the contract but in its development it experienced ups and downs, unlike the principle of good faith which showed a stronger function, freedom of contract actually experienced a functional decline due to strong State intervention in limiting individuals in creating and regulating contractual relationships. ${ }^{22}$.

Civil law applicable in Indonesia recognizes the existence of freedom of contract, this can be concluded from the provisions of Article 1338 paragraph (1) of the Civil Code, which states that all contracts (agreements) that are legally made apply as law for those who make them. The source of freedom of contract is individual freedom, so that the point of departure is individual interests as well. Thus, it can be understood that individual freedom gives him the freedom to contract.

Freedom of contract is the basis for securities companies in carrying out contractualization actions. This is reflected for example in the right of cancellation, contract renewal or unilateral determination of sanctions by the securities company as stipulated in the provisions of article 12 paragraph (3) of the Securities Transaction Settlement Financing Agreement, namely that the Securities Company has the right to unilaterally terminate the securities transaction

${ }^{22}$ Endi Budiman. Op.cit., p. 113. 
settlement financing agreement. To protect the possibility of harm to individuals, especially securities companies, a law is ultimately needed as a basis for the court to decide. In this context, appropriate boundaries are needed that can be used as a reference.

Basically, the legal protection arising from the financing agreement for the settlement of securities transactions is materially protected. It is said to have been protected because it has fulfilled the legal requirements of an agreement according to Article 1320 of the Civil Code, namely:

- There is an agreement between the two parties, the meaning of the agreement is that both parties who make an agreement agree on the main things in the contract

- The ability to take legal action. The principle of being able to carry out legal actions is that everyone is an adult and has a sound mind. There are several opinions regarding the provisions for adulthood, according to the Civil Code, adults are 21 years for men and 19 years for women.

- There is an object. Something that is promised in an agreement must be something that is quite clear.

- The existence of a lawful cause, an agreement that does not use a lawful cause, or is made with a false or forbidden cause, has no legal force because it has fulfilled all of the above conditions, it can be said that the agreement has binding legal force. But not formally. This is because the legal position of the securities transaction settlement financing agreement is only in the form of a form, including an underhand agreement that does not meet the formality requirements.

An agreement that has fulfilled the formal requirements will have stronger evidentiary power. An agreement is said to have fulfilled the formal requirements if the agreement between the two parties is stated in the form of a certain deed and ratified by an authorized official in this case a notary. In this regard, it is necessary to strengthen the relationship between the securities company and the customer/investor in the sense that the relationship is not only stated in one form but must be stated in an authentic deed made by an authorized official, namely a notary, including the provision of guarantees by the customer/investor., so that it has binding legal force as strong evidence for the parties as well as to third parties regarding the existence of a legal relationship between the Securities company and the Customer/Investor in carrying out margin trading and forced sells. Even though according to the provisions of Article 1338 of the Civil Code, all legally made agreements apply as law for the parties who make them. However, even though the formality requirements are not fulfilled, namely made before an authorized official, it does not mean that the Securities Transaction Settlement Financing agreement (including the provision of guarantees) is void, but as an ordinary agreement that does not provide the position of preference rights and executive power for creditors (securities companies). Even though according to the provisions of Article 1338 of the Civil Code, all legally made agreements apply as law for the parties who make them. However, even though the formality requirements are not fulfilled, namely made before an authorized official, it does not mean that the Securities Transaction Settlement Financing agreement 
(including the provision of guarantees) is void, but as an ordinary agreement that does not provide the position of preference rights and executive power for creditors (securities companies). Even though according to the provisions of Article 1338 of the Civil Code, all legally made agreements apply as law for the parties who make them. However, even though the formality requirements are not fulfilled, namely made before an authorized official, it does not mean that the Securities Transaction Settlement Financing agreement (including the provision of guarantees) is void, but as an ordinary agreement that does not provide the position of preference rights and executive power for creditors (securities companies).

The results of research regarding the protection of investors' rights in the analysis of margin transaction financing by Stock Exchange Companies when a forced sale of shares is carried out in Indonesia can be seen in various forms of agreements which are the implementation of the principle of freedom of contract between securities companies and customers/investors, one of which is rights. and obligations of the parties as a form of legal protection. This principle is a topic in every legal study relating to contracts. This may be the most important domain in the contract but in its development it has ups and downs, unlike the principle of good faith which shows a stronger function, ${ }^{23}$.

Agreements or contracts that occur in margin transactions occur because of an agreement, which can be used as a benchmark to determine a person's attachment to a closed agreement so that the agreement is considered to have entered into force. Contracts that occur in margin transactions or forced selling are a form of agreement between the two parties to an existing agreement, where the agreement on the contract creates an attachment between the parties which in this case is between a securities company and a customer/investor, so that with this , then the principle of freedom of contract is very visible in margin transactions.

The margin transaction agreement is the result of an agreement between the parties involved, even though in reality the contract is not the result of a balanced negotiation between the two parties, but a form of contract that can be categorized as a standard contract where the contract existed before an agreement was reached in which one of the parties submits to the other party which then the other party simply agrees to the contract, so that the application of the principle of consensualism according to Indonesian contract law strengthens the principle of freedom of contract.

The principle of freedom of contract (contractvrijheid) relates to the contents of the agreement, namely the freedom to determine "what" and "with whom" the agreement is made. The agreement made in accordance with Article 1320 of the Civil Code has binding power, so that with the principle of freedom of contract and the open nature of Book III of the Civil Code, the parties in the margin transaction are free to determine the contents of the agreed contract which will ultimately be binding on both parties sides. Freedom of contract is important in supporting the interests of economic actors. It is this freedom that ultimately gives

${ }^{23}$ Yohanes Sogar Simamora. (2009). Hukum Perjanjian, Prinsip Hukum Kontrak Pengadaan Barang dan Jasa Oleh Pemerintah. Yogyakarta: LaksaBang, p. 38 
birth to the adhesion contract. Contracts which were originally individual in nature developed into collectives and, more importantly, with the nature of adhesion, there was a release of responsibility due to non-performance of an obligation. ${ }^{24}$ Contracts that contain the nature of adhesion are clear implications and this is common in contracts made by the government. This is reflected, for example, in the existence of cancellation rights, contract renewals or the determination of sanctions unilaterally determined by securities companies.

To protect the possibility of causing losses to securities companies, a law is needed as a basis for the court to decide. In this context, appropriate boundaries are needed that can be used as a reference. Legal protection for securities companies in margin transactions is related to the provision of guarantees by investors. Basically, the protection of securities companies in the current conditions in the practice of margin transactions and forced selling is materially protected, but not formally. This is because the legal position of the agreement which is only in the form of a form including an agreement made under the hand is an agreement that does not meet the formality requirements, even though according to the provisions of Article 1338 of the Civil Code, all legally concluded engagements apply as law for the parties who make them. However, even though the formality requirements are not fulfilled, it does not mean that the financing agreement for the settlement of securities transactions (including the provision of guarantees) is void, but as an ordinary agreement that does not give the creditor (securities company) preferential rights and executive powers.

Actions that can be taken to protect investors' rights in the analysis of margin transaction financing by a Stock Exchange Company when a share sale is enforced in a progressive legal perspective through an internal control system and the implementation of a haircut by a securities company, which can be explained that in internal control This is also found in stock trading. Bapepam-LK as the supervisor of the capital market in Indonesia has issued a regulation on internal control, namely Bapepam-LK Regulation No. VD3 of 2010. The regulation stipulates that every securities company that conducts transactions for the benefit of nonaffiliated parties must have at least four sections or functions, including marketing function, risk management function, bookkeeping function, custodian function ${ }^{25}$.

The implementation of these 6 functions in securities companies is intended to prevent overlapping work in securities companies, which can be complemented by the implementation of Single Investor ID in line with the Indonesian Capital Market Infrastructure Development program launched by Bapepam-LK together with the Self Regulatory Organization (SRO). . The launch of the access facility on June 18, 2009 which is a protection for investors in investing in the capital market through the disclosure of information on their investment portfolios kept at KSEI, is the first step in implementing Single Investor ID. With the AKSes card, investors can carry out independent supervision to reduce the risk of misuse of investor securities by irresponsible parties.

\footnotetext{
${ }^{24}$ Munir Fuady. (1999). Hukum Kontrak Dari Sudut Hukum Bisnis. Bandung: PT. Citra Aditya Bakti, p.39.

${ }^{25}$ Number 3 Bapepam-LK Regulation No. VD3 of 2010
} 
Another action that can be applied is implementing a haircut mechanism. The trading limit imposed on exchange members is 24 times the total free collateral. This trading limit is a risk control tool that uses a collateral or collateral approach in its calculations. Meanwhile, haircut is a factor that reduces the fair market value of securities in accordance with the risk of a certain percentage of the fair market value of the securities.

Collateral required by KPEI for clearing members (AK) consists of online and offline collateral. The online collateral referred to is money and or securities contained in the collateral account of each CM at KSEI. While the offline collateral in question is collateral outside the money and securities in the collateral account, namely stock exchange certificates, certificates of deposit, and bank guarantees. With the trading limit, the risk of failure of settlement can be minimized. This is because any obligations arising from CM transactions on the stock exchange will be calculated from the value of the collateral pledged to KPEI. Thus, if the CM fails to fulfill its obligations to KPEI at maturity, then KPEI, which acts as the guarantor, still has collateral to cover the market risk that may arise.

Roughly speaking, the collateral currently set by KPEI is around $20-25 \%$ of the value of buying and selling transactions after netting. This figure is considered sufficient for stocks that are classified as liquid but on the other hand too small for other stocks, where the risk of price fluctuations can be much higher than that and not necessarily liquid either. Based on this explanation, adjustments can be made to the amount of collateral and hair cut. Ideally, each stock has a different hair cut and collateral requirements.

The existence of the collateral can be used to provide guarantees that contain a wealth (material) or a statement of ability (immaterial) which can be used as a source of debt repayment in the event of default, the lender can have the collateral. This guarantee is a matter that is very closely related to the bank in the technical implementation of lending. Credit provided by the bank needs to be secured. Without security, it is difficult for banks to avoid future risks, as a result of a customer's underperformance. To get certainty and security from their credit, the bank takes security measures and asks prospective customers to bind certain goods as collateral in granting credit. The purpose of using this guarantee is to provide certainty and security of its credit, securities companies take security measures and ask prospective customers to bind certain goods as collateral in granting credit and are regulated in Articles 1131 and 1132 of the Civil Code.

In relation to the guarantee provided by the customer, in addition to the existence of a margin securities account, to protect the funds that have been provided by the securities company in the form of financing facilities or value, the securities transaction settlement financing agreement has regulated several things, including:

- Client's regular securities account, which is a securities account in the name of the customer that must be opened at a securities company that contains notes regarding the position of securities and/or funds owned by the customer; and

- Margin deposit, which is the total value of collateral in the form of money and/or securities (which will be valued in money) and must have an adequate 
and acceptable value according to the consideration of the securities company in the margin securities account.

The value of the financing guarantee that must be maintained by the customer is at least $135 \%$ of the fair market value of the securities transacted by forced selling (short position). If the value of the guarantee has decreased to less than $135 \%$, then the customer is required to add collateral within 3 trading days so that the guarantee value is at least $135 \%$. If within 3 trading days the customer does not deposit additional collateral, then on the 4th trading day since this condition occurs, the securities company is obliged to purchase securities in a short position so that the collateral value is at least 135\%. Furthermore, if the collateral value is less than $120 \%$, then the securities company is required to purchase securities in the short position so that the collateral value is at least $135 \%$ of the fair market value of the securities in the said short position. ${ }^{26}$ In addition, to guarantee repayment of customer debts to securities companies and to ensure the fulfillment of all customer obligations to securities companies arising from financing agreements for securities transaction settlements and/or other agreements that now exist/or are made in the future between customers and securities companies, then The customer will provide additional guarantees including making a notarial acknowledgment of debt for the facility or the value of the financing plus interest and other fees payable.

In this regard, it is necessary to affirm the relationship between the company and investors in the sense that the relationship is not only stated in a form but must be stated in an authentic deed made by an authorized official, namely a notary. This includes the provision of guarantees by investors, so that they have binding legal force as strong evidence for the parties and for third parties, regarding the existence of a legal relationship between securities companies and investors.

\section{Clossing}

The concept of ideal investor legal protection in the sale of shares by force in the financing of margin transactions includes preventive legal protection and repressive protection. As preventive legal protection, the formation of law must be carried out democratically and the resulting legal products must be able to accommodate the protection of human rights, protect the interests of the parties in it and be predictive in nature to be a reference for action. Repressive legal protection regulates dispute resolution. Several provisions in Bapepam-LK Regulation Number VD6 on Financing of Securities Transactions by Securities Companies for Customers and Short Selling Transactions by Securities Companies should be amended. Changes are needed regarding the subject matter of the agreement as regulated in number 4 which is contrary to the legality of the standard clauses in the Consumer Protection Law. The mechanism for forced selling of shares must also be further regulated so that crossing practices that tend to harm customers/investors can be avoided. Number 6 letter $\mathrm{b}$ point 8 regarding confirmation of post-force sale of shares should not be limited to confirmation in

${ }^{26}$ Number 6 letter c point 7 Bapepam-LK Regulation No. VD6 
writing. Implementation of protection of investor rights in the analysis of margin transaction financing by Stock Exchange Companies when selling shares by force has been implemented through a contract accompanied by the implementation of an internal control system and the implementation of haircuts by the IDX. In connection with the findings of the research and discussion, the suggestion that can be conveyed by the author is that the protection of investors' rights for the occurrence of forced sales in securities companies can be carried out through the imposition of administrative sanctions on violators of the rules as an ultimum remedium which must be explained in detail in capital market regulations and protection. Investors' rights to the occurrence of forced sales in securities companies in a progressive legal perspective can be carried out through the implementation of good governance in order to create a system of information transparency and increase IDX's accountability, so that a system of equality and fairness is realized, as well as accountability in order to accommodate the interests of shareholders.

\section{References}

\section{Journals:}

[1] Agung Sudjati Winata. Perlindungan Investor Asing dalam Kegiatan Penanaman Modal Asing dan Implikasinya Terhadap Negara. 2018. AJUDIKASI: Jurnal Ilmu Hukum, Vol. 2 No. 2. December 2018. p. 127. Source: file://C:/Users/user/AppData/Local/Temp/902-Article\%20Text-2890-110-20181231-1.pdf

[2] Bagus Sujatmiko and Nyulistiowati Suryanti. Perlindungan Hukum Bagi Investor Pada Perusahaan Terbuka Yang Pailit Ditinjau dari Hukum Kepailitan. Jurnal Bina Mulia Hukum Volume 2, No. 1, September 2017. p. 16. Source: https://jurnal.fh.unpad.ac.id/index.php/ibmh/article/view/88/41

[3] Chuasanga A., Ong Argo Victoria. (2019). Legal Principles Under Criminal Law in Indonesia and Thailand, Jurnal Daulat Hukum, Vol 2, No 1 (2019) http://jurnal.unissula.ac.id/index.php/RH/article/view/4218

[4] Fitria Dina. 2015. Perlindungan Hukum Terhadap Investor Dalam Hal Jual Paksa (Forced Sell) Di Pasar Modal (Studi Di Pt. Bni Securities Padang). Diploma Thesis, Upt. Perpustakaan Unand. URL. https://onesearch.id/Record/IOS3153.115

[5] Juli Asril. 2019. Margin Trading Di Pasar Modal Dan Regulasinya Di Indonesia. Jurnal Ilmiah Mea (Manajemen, Ekonomi, \& Akuntansi), Vol. 3, No. 1 , 256-273.

URL http://journal.stiemb.ac.id/index.php/mea/article/view/819.

[6] Ria Sintha Devi. Perlindungan Hukum Bagi Penanaman Modal Asing (PMA) Di Indonesia. 2019. Jurnal Rectum, volume I, No. 2, July 2019. p. 142. Source:https://jurnal.darmaagung.ac.id/index.php/jurnalrectum/article/vie $\mathrm{w} / 227$

\section{Books:}


[1] Endi Budiman. (2010). Perlindungan Hukum terhadap Perusahaan Sekuritas dalam Transaksi atas Fasilitas Margin Trading. Semarang: Universitas Diponegoro.

[2] Irsan Nasaruddin, et.all. (2011). Aspek Hukum Pasar Modal Indonesia, cet. 7. Jakarta: Kencana Prenada Media Group.

[3] Jimly Asshiddiqie. (2011). Perihal Undang-Undang, cet.II. Jakarta: PT. Rajagrafindo Persada.

[4] Jusuf Anwar. (2005). Pasar Modal Sebagai Sarana Pembiayaan dan Investasi. Bandung: Alumni.

[5] Munir Fuady. (1999). Hukum Kontrak Dari Sudut Hukum Bisnis. Bandung: PT. Citra AdityaBakti.

[6] Phillipus M. Hadjon. (1988). Perlindungan Hukum bagi Rakyat Indonesia. Surabaya:Bina Ilmu.

[7] Soerjono Soekanto and Sri Mamudji. (1985). Penelitian Hukum Normatif Suatu Tinjauan Singkat. Jakarta: Rajawali Pers.

[8] Subekti and R. Tjitrosubidio. (1996). Kitab Undang-Undang Hukum Perdata. Jakarta: PT. Pradnya Paramita.

[9] Yohanes Sogar Simamora. (2009). Hukum Perjanjian, Prinsip Hukum Kontrak Pengadaan Barang dan Jasa Oleh Pemerintah. Yogyakarta: LaksaBang.

\section{Internet :}

[1] Alicia Tuovila. 2021. Forced Selling (Forced Liquidation). Source: Investopedia, Edition 30 Juni 2021 Https://Www.Investopedia.Com,

[2] Anonim. 2020. Hindari Forced Sell Saat Pakai Limit Trading Dengan Fasilitas Marjin. Source: Https://Www.Most.Co.Id,

[3] Anonim. 2009. Aksi Jual Paksa Saham Milik Nasabah Dipertanyakan. Source: Detikfinance, Edition 28 January 2009. Https://Finance.Detik.com.,

[4] Anonim. 2020. Manipulasi Harga Saham. Http://Www.Capital-Asset.Co.Id.,

[5] Jimly Asshiddiqie. No year. Konsep Negara Hukum. Source: www.jimly.com.

[6] Kiki Safitri. 2021. Mau Main Saham Pakai Margin Trading, Pahami Mekanismenya Supaya Tidak Terjebak Kerugian. Source Kompas, Edition 20 January 2021. Accessed from Https://Money.Kompas.Com,

\section{Others:}

[1] Decision of the Chairman of BAPEPAM-LK No. KEP-556/BL/2008 Financing of Securities Transactions by Securities Companies for Customers and Short Selling Transactions by Securities Companies

[2] OCBC Securities. 2018. Securities Transaction Financing Agreement Margin Securities Financing Account Agreement For Margin Transaction. Article 13 Regarding Forced Sales. 